\title{
ОЦІНКА ЯКОСТІ НАДАННЯ МЕДИЧНОЇ ДОПОМОГИ НА РІВНІ ПЕРВИННОЇ ЛАНКИ НАСЕЛЕННЯМ М. УЖГОРОДА ТА УЖГОРОДСЬКОГО РАЙОНУ
}

\author{
ДВНЗ «Ужгородський національний університет», м. Ужгород, Україна
}

\begin{abstract}
Мета: визначити рівень якості медичної допомоги, яку надають населенню м. Ужгорода та Ужгородського району в закладах первинної ланки (сімейні амбулаторії, центри ПМСД).

Матеріали і методи. Основним завданням дослідження було визначення ступеня задоволеності пацієнтів якістю медичної допомоги на рівні первинної ланки. Дослідження проводили шляхом електронного анкетування. У вибірку включено 130 осіб віком 18-65 років жителів м. Ужгорода та Ужгородського району.

Результати. Більшість респондентів (51,5 \%) дала позитивну загальну оцінку якості надання медичних послуг на рівні первинної ланки (оцінки «добре» та «дуже добре»). Нейтральну оцінку дали 36,9 \% респондентів. 11,6 \% висловились негативно (оцінки «незадовільно» та «абсолютно незадовільно») стосовно якості отриманих медичних послуг. Учасників опитування попросили проаналізувати свій останній візит до їхнього сімейного лікаря. Серед труднощів, з якими стикаються пацієнти при зверненні до сімейного лікаря, найпоширенішими $є$ довгі черги на прийом до лікаря, некомсортні зони очікування та незручний графрік прийому. На думку респондентів, для покращення якості надання медичної допомоги в амбулаторіях та центрах ПМСД можна зробити наступне: надати можливість онлайн-запису до лікаря та отримання попередньої консультації за допомогою відеозв'язку, узгодити графріки прийому сімейних лікарів, вузьких спеціалістів та робочі години лабораторії, можливість здати аналізи безпосередньо в амбулаторії, збільшити кількість медичного персоналу, покращити матеріально-технічні умови амбулаторій. Даючи загальну оцінку якості медичної допомоги на рівні первинної ланки, 11,5 \% респондентів дали оцінку «дуже добре», 40 \% обрали варіант «добре». Задовільною якість медичних послуг вважають 36,9 \% опитаних, незадовільною - 6,2 \% та абсолютно незадовільною - 5,4 \%.

Висновки. Більшість респондентів дала позитивну загальну оцінку якості надання медичних послуг на рівні первинної ланки. На думку респондентів, поліпшити якість послуг можна шляхом більш широкого використання технологій для покращення комунікації між закладом первинної ланки та пацієнтами (наприклад, можливість онлайн-запису на прийом та контакту з лікарем за допомогою відеозв'язку).
\end{abstract}

КЛЮЧОВІ СЛОВА: сімейна медицина; оцінка якості медичних послуг; первинна ланка медичної допомоги.

Всесвітня організація охорони здоров'я визначила первинну ланку медичної допомоги основним інструментом для вирішення завдання досягнення «здоров'я для всіх» і фрудаментом всієї системи медичного обслуговування, а центральною фрігурою первинної ланки - лікаря загальної практики - сімейного лікаря $[1,5]$.

У жовтні 2017 р., прийняттям Верховною Радою України законопроекту № 6327 «Про державні фрінансові гарантії надання медичних послуг та лікарських засобів», розпочалась медична реформа в Україні. Відповідно до Закону України № 6327 держава гарантує повну оплату коштом держбюджету України необхідних медичних послуг і лікарських засобів, пов'язаних із наданням екстреної медичної допомоги, первинної, вторинної (спеціалізованої), третинної, паліативної медичної допомоги, медичної реабілітації, медичної допомоги дітям до 16 років, а також супроводу вагітності та пологів [3]. У квітні 2018 р. розпочався перший етап реформи, який передбачав підписання декларацій між пацієнтами і сімейними

(c) А. Р. Іваць-Чабіна, 2020 лікарями та можливість для пацієнта самостійно обирати лікаря [4].

Серед критеріїв якості медичної допомоги населенню важливу роль відводять суб'єктивній оцінці самих пацієнтів різних аспектів медичного обслуговування [2]. 3 цією метою проведено медико-соціологічне дослідження, участь в якому взяли респонденти - жителі м. Ужгорода та Ужгородського району віком 18-65 років. Учасникам запропоновано проаналізувати переваги і недоліки отриманих ними медичних послуг, дати загальну оцінку цим послугам, висловити власну думку стосовно можливості покращення обслуговування населення у медичних закладах на рівні первинної ланки.

Мета роботи: визначити рівень якості медичної допомоги, яку надають населенню м. Ужгорода та Ужгородського району в закладах первинної ланки (сімейні амбулаторії, центри ПМСД).

Матеріали і методи. Основним завданням дослідження було визначення ступеня задоволеності пацієнтів якістю медичної допомоги на рівні первинної ланки. Дослідження проводили 
шляхом електронного анкетування. У вибірку включено 130 осіб віком 18-65 років жителів м. Ужгорода та Ужгородського району.

Результати дослідження та їх обговорення. В опитуванні взяли участь 130 респондентів. 53,8 \% жінок, 46,2 \% чоловіків. 6,2 \% опитаних віком 18-24 роки, 39,2 \% - 25-34 роки, 33,1 \% 35-44 роки, 13,1 \% - 45-54 роки та 8,5 \% віком 55-64 роки.

82,3 \% респондентів проживають у міській місцевості, а решта (17,7 \%) є жителями сільської.

96,9 \% учасників підписали декларацію з сімейним лікарем та лише 3,1 \% не укладали договір.

$60 \%$ респондентів уклали договір із лікарем у державній амбулаторії за місцем проживання. 20 \% обрали лікаря в амбулаторії не за місцем проживання. 16,2 \% підписали декларацію 3 лікарем у приватному медичному центрі. 3,8 \% не визначились 3 вибором спеціаліста.

Протягом останніх трьох років 24,6 \% респондентів звертались до сімейного лікаря рідше одного разу на рік.

За останні три роки 28,5 \% респондентів звертались до сімейного лікаря в середньому 1-2 рази на рік. 41,5 \% звертаються до лікаря частіше, ніж 1-2 рази на рік, а 5,4 \% відвідують свого сімейного лікаря не рідше одного разу на місяць.

Респондентів попросили проаналізувати свій останній візит до сімейного лікаря, оцінити організацію роботи амбулаторії, ефективність призначеного лікування та загальне враження від отриманих медичних послуг.

На запитання «Чи користувались Ви послугою попереднього запису до свого лікаря?» учасники відповіли таким чином: 53,8 \% скористались можливістю попереднього запису та потрапили на прийом у призначений час; 10,8 \%, попередньо записавшись, потрапили в кабінет лікаря пізніше через черги, а 35,4 \% не користувались даною послугою.

За причинами звернення поділ був таким: 43,8 \% звернулись за консультацією до лікаря, 27,7 \% потребували лікування через погіршення самопочуття, 10,8 \% потребували оформлення довідки або лікарняного листка, 16,2 \% опитаних відвідували амбулаторію, щоб отримати профілактичне щеплення, а 1,6 \% звернулись за направленням до вузькопрофрільного спеціаліста.

Респонденти повинні були оцінити свою задоволеність результатами лікування, яке їм лікар призначив під час останного візиту. 22,3 \% повністю задоволені результатами лікування, 39,2 \% оцінюють результати як переважно позитивні, 5,4 \% переважно не задоволені результатами лікування, а 3,8 \% характеризують проведене лікування як абсолютно неефективне. 20,5 \% дали нейтральну оцінку. Для 8,7 \% респондентів лікар не призначав лікування.

Причини негативної оцінки лікування були такими: 3,1 \% повідомили, що через призначені ліки у них виникли серйозні побічні ефекти, 16,2 \% не помітили змін у самопочутті, 2,3 \% відзначили погіршення стану, а 0,8 \% не виконували призначення лікаря.

На запитання «Чи стикались Ви 3 якимись труднощами при зверненні до сімейного лікаря» 51,5 \% відповіли ствердно, а 48,5 \% не стикались з жодними проблемами. Респондентам запропоновано обрати з переліку пункти, що стосуються труднощів, з якими вони стикнулись при зверненні до сімейного лікаря. Поділ був таким: 16,9 \% відзначили довгі черги до кабінету, 16,9 \% поскаржились на некоморортне місце для очікування (мало простору, темно, некомфортно тощо), 10,0% вважають незручним графрік прийому свого сімейного лікаря, 8,5 \% учасників повідомили про те, що потрібної їм вакцини не було в наявності, 6,9 \% респондентів зазначили, що в сімейній амбулаторії не надають необхідні їм послуги, 6,2 \% поскаржились на те, що лікаря не було на місці в години прийому, 4,6 \% вважають умови в кабінеті лікаря некомфортними та ще 3,8 \% відзначають високу вартість призначених препаратів.

Серед пропозицій щодо покращення якості надання медичної допомоги у закладах первинної ланки учасники опитування назвали такі:

1) надати можливість онлайн-запису до лікаря;

2) узгодити графріки прийому сімейних лікарів, вузьких спеціалістів і робочі години лабораторії;

3) можливість здати аналізи безпосередньо в амбулаторії;

4) можливість отримати попередню консультацію в режимі онлайн за допомогою відеозв'язку;

5) збільшити кількість медичного персоналу.

6) покращити матеріально-технічні умови амбулаторій (ремонт приміщень, модернізація обладнання, встановити потужніші комп'ютери тощо).

Також респондентів попросили дати загальну оцінку якості надання медичних послуг на рівні первинної ланки. 11,5 \% дали оцінку «дуже добре», 40,0 \% обрали варіант «добре». Задовільною якість медичних послуг вважають 36,9 \% опитаних, незадовільною - 6,2 \% та абсолютно незадовільною - 5,4 \%.

\section{Висновки}

1. Більшість респондентів (51,5\%) дала позитивну загальну оцінку якості надання медичних послуг на рівні первинної ланки (оцінки «добре» та «дуже добре»).

2. Нейтральну оцінку дали 36,9 \% респондентів.

3. $11,6 \%$ висловились негативно (оцінки «незадовільно» та «абсолютно незадовільно») стосовно якості отриманих медичних послуг. 
4. Серед труднощів, з якими стикаються пацієнти при зверненні до сімейного лікаря, найпоширенішими є довгі черги на прийом до лікаря, некомфрортні зони очікування та незручний графік прийому, відсутність необхідних вакцин.

5. Серед пропозицій щодо покращення якості надання медичних послуг на рівні первинної ланки респонденти акцентували увагу на більш широкому впровадженні новітніх технологій та можливості записуватись на прийом і контактувати з лікарем через мережу «нтернет».

Перспективи подальших досліджень полягають у більш детальному вивченні фракторів, що впливають на рівень якості медичної допомоги на рівні первинної ланки, та фракторів, від яких залежить ступінь задоволеності населення наданими медичними послугами.

\section{Список літератури}

1. Науково обґрунтовані підходи до кваліфрікаційної характеристики лікаря загальної практики - сімейного лікаря з позиції компетентнісного підходу : методичні рекомендації / уклад. : Л. Ф. Матюха, Н. Г. Гойда, В. Г. Слабкий, М. В. Олійник. - К. : НМАПО ім. П. Л. Шупика, ДУ «УІСД МОЗ України», 2010. - 27 с.

2. Організація контролю якості медичної допомоги в закладах охорони здоров'я : методичні рекомендації [Електронний ресурс] / Ю. Вороненко, Н. Гойда, О. Децик та ін. - К., 2014. - Режим доступу : http://dec.gov.ua/wpcontent/uploads/2019/11/oky_zoz.pdf.

3. Про державні фрінансові гарантії медичного обслуговування населення : Закон України від 19 жовтня 2017 року № 2168-VIII / Відомості Верховної Ради України. - 2017. - № 5 - Ст. 31.

4. Як обрати лікаря? [Електронний ресурс] / Міністерство охорони здоров'я України. - Режим доступу : http://moz. gov.ua/article/reform-plan/videoroliki-chatboti-sajti-jak-u-regionah-rozpochali-kampaniju-z-viboru-likarja.

5. People-centred and integrated health services: an overview of the evidence: interim report. World Health Organization. [Електронний ресурс] // World Health Organization. - 2015. -Access mode : http://apps.who.int/iris/handle/10665/155004

\section{References}

1. Matiukha, L.F., Hoida, N.H., Slabkyi, V.H., \& Oliinyk, M.V. (2010). Naukovo obhruntovani pidkhody do kvalifikatsiinoi harakterystyky likaria zahalnoi praktyky/simeinoho likaria z pozytsii kompetentisnoho pidkhodu [Scientific substantiated approaches to the qualification characteristics of a general practitioner/family doctor from the standpoint of a competency approach]. Kyiv: NMAPO by P.L. Shupyka [in Ukrainian].

2. Voronenko, Yu., Hoida, N., Detsyk, O., Zimenkovskyi, A., Krishtopa, B., \& Latyshev, Ye. (2014). Orhanizatsiia kontroliu yakosti medychnoi dopomohy $v$ zakladakh okhorony zdorovia [Organization of quality control of medical care in health care facilities]. Kyiv. Retrieved from: https://dec.gov.ua/wp-content/uploads/2019/11/oky_zoz.pdf

3. (2017). Zakon Ukrainy "Pro derzhavni finansovi harantii medychnoho obsluhovuvannia naselennia" vid 19 zhovtnia 2017 roku № 2168-VIII [Law of Ukraine "On state financial guarantees of medical care" of October 19, 2017 No. 2168-VIII]. Vidomosti Verhovnoi Rady Ukrainy - Information of the Verkhovna Rada of Ukraine, 5, 31 [in Ukrainian].

4. (2018). Ministerstvo okhorony zdorovia Ukrainy [Ministry of Health of Ukraine]. Retrieved from: http://moz.gov.ua/article/ reform-plan/videoroliki-chatboti-sajti-jak-u-regionah-rozpochali-kampaniju-z-viboru-likarja [in Ukrainian].

5. (2015). People-centred and integrated health services: an overview of the evidence: interim report. World Health Organization. Retrieved from: http://apps.who.int/iris/handle/10665/155004

\section{ASSESSMENT OF THE QUALITY OF MEDICAL CARE TO THE POPULATION OF UZHHOROD AND UZHHOROD DISTRICT AT THE PRIMARY CARE LEVEL}

A. R. Ivats-Chabina

Uzhhorod National University, Uzhhorod, Ukraine

Purpose: to determine the level of quality of medical care provided to the population of Uzhhorod and Uzhhorod district in primary care facilities (family outpatient clinics and primary care centers).

Materials and Methods. The main objective of the study was to determine the level of patient satisfaction with the quality of primary medical care. The study was conducted by electronic questionnaire. The sample included 130 people aged 18 to 65 years, who live in Uzhhorod and Uzhhorod district.

Results. The majority of respondents (51.5\%) gave a positive overall assessment of the quality of the provision of medical services at the primary level ("good" and "very good" ratings). A neutral rating was given by $36.9 \%$ of respondents. $11.6 \%$ expressed a negative opinion (assessments "unsatisfactory" and "absolutely unsatisfactory") regarding the quality of medical services received. Participants were asked to analyze their last visit to their family doctor. Among the difficulties that patients encounter when contacting a family doctor, the most common are: long lines for an appointment with a doctor, uncomfortable waiting areas and an inconvenient appointment schedule. According to respondents, improving the quality of services may be reached by providing an opportunity of online visit scheduling and contacting a doctor via video calls, coordination reception schedules for family doctors, narrow specialists and laboratory working hours, and the opportunity to be tested directly in the outpatient clinic, increasing the number of medical personnel, improving the material and technical conditions of the outpatient clinic. The overall assessment of medical services quality was as follows: $11.5 \%$ of respondents rated "very good", $40 \%$ chose the option "good". A neutral rating was given by $36.9 \%$ of respondents. Unsatisfactory $-6.2 \%$ and absolutely unsatisfactory $-5.4 \%$. 
Conclusions. Most respondents gave a positive overall assessment of the quality of medical services at the primary care level. According to respondents, improving the quality of services may be reached by using technology for simplifying communication between the primary care institution and patients (for example, the possibility of online visit scheduling and contacting a doctor via video calls).

KEY WORDS: family medicine; assessment of the quality of medical services; primary health care.

Рукопис надійшов до редакції 12.05.2020 р.

\section{Відомості про автора:}

Іваць-Чабіна Анна Романівна - асистент кафедри наук про здоров'я фракультету здоров'я та фрізичного виховання ДВНЗ «Ужгородський національний університет»; тел.: +38(068) 632-03-15. 